\title{
Rapid multiplication and in vitro production of leaf biomass in Kaempferia galanga through tissue culture
}

\author{
Reena Parida \\ Centre of Biotechnology \\ Siksha 'O' Anusandhan University \\ PO- Khandagiri, Bhubaneswar-751030 \\ Orissa, India \\ Sujata Mohanty \\ Centre of Biotechnology \\ Siksha 'O' Anusandhan University \\ PO- Khandagiri, Bhubaneswar-751030 \\ Orissa, India \\ Ananya Kuanar \\ Centre of Biotechnology \\ Siksha 'O' Anusandhan University \\ PO- Khandagiri, Bhubaneswar-751030 \\ Orissa, India

\section{Sanghamitra Nayak*} \\ Centre of Biotechnology \\ Siksha 'O' Anusandhan University \\ PO- Khandagiri, Bhubaneswar-751030 \\ Orissa, India \\ E-mail: sanghamitran@yahoo.com
}

Keywords: growth regulators, Kaempferia, in vitro propagation, leaf biomass.

\author{
Abbreviations: BA: Benzyladenine \\ Ads: Adenine sulphate \\ IAA: Indoleacetic acid \\ IBA: Indolebutyric acid \\ NAA: Napthaleneacetic acid \\ RAPD: Random Amplified Polymorphic DNA
}

An efficient protocol has been established for rapid multiplication and in vitro production of leaf biomass in Kaempferia galanga $\mathrm{L}$, a rare medicinal plant. Different plant growth regulators like Benzyladenine (BA), Indoleacetic acid (IAA), Indolebutyric acid (IBA), Napthaleneacetic acid (NAA) and adenine sulphates (Ads) have been tried for induction of multiple shoots using lateral bud of rhizome as explants. The highest rate of shoot multiplication (11.5 $\pm \mathbf{0 . 6})$ shoot/explant as well as leaf biomass production $(7.4 \pm 0.3)$ gram/explant was observed on Murashige and Skoog medium supplemented with Benzyladenine $(1 \mathrm{mg} / \mathrm{l})$ and Indoleacetic acid $(0.5 \mathrm{mg} / \mathrm{l})$. Data of shoot multiplication and leaf biomass production were statistically analysed. Upon excission of leaves after 2 months of culture under sterile condition, the base of each plantlet was transferred to fresh media which could produce the same leaf biomass within another 2 months in a $50 \mathrm{ml}$ culture tube containing $20 \mathrm{ml}$ and $250 \mathrm{ml}$ conical flasks containing $30 \mathrm{ml}$ Murashige and Skoog medium. The rate of multiplication and leaf biomass production remained unchanged in subsequent subcultures. The regenerated plantlets were acclimatized in greenhouse and subsequently transferred to the field. Survival rate of the plantlets under ex vitro condition was 95 percent. Genetic fidelity of the regenerants was confirmed using random amplified polymorphic DNA (RAPD) marker. The protocol could be commercially utilized for large scale production of true-to-type plantlets and as an alternative method of leaf biomass production in Kaempferia galanga.

Kaempferia galanga L. (K. galanga) is a rare Indian medicinal herb of family Zingiberaceae. It is distributed in the tropics and subtropics of Asia and Africa. The plant is extensively used in preparation of ayurvedic drugs, in perfumery, cosmetics and as spice ingredients (Rahman et al. 2004). The plant is used for treatment of diarrhea,

*Corresponding author 
migraine and it increases energy to overcome exhaustion. Leaves of $K$. galanga are used in flavouring foodstuffs, hair tonics, mouth washes and also in cosmetic industries. The leaves possess antioxidant, antinociceptive and antiinflammatory activities that help in treatment of mouth ulcers and headaches (Sulaiman et al. 2008; Chan et al. 2009). The poultices of leaves as well as the tea of leaves are used for curing sore throat, rheumatism, swellings and eye infections, whereas the leaf infussions of K.galanga can be used as a beneficial drink for pregnant women (Rahman et al. 2004; Sulaiman et al. 2008). The ashes of leaves are rubbed on swollen breasts after childbirth but fresh leaves are chewed for relieving coughs (Sulaiman et al. 2008). The plant is wild in nature and exhibits poor natural regeneration by rhizomes thus reaching the threshold of being recognized as an endangered species (Shirin et al. 2000). Large scale deforestation and over exploitation further reduces the plant population. K. galanga is rarely cultivated at some places for medicinal purposes. Conventional propagation of Kaempferia by the splitting of rhizome is not sufficiently rapid to meet the need of planting materials and leaves, and it takes years to build up for the commercial quantities. In the recent years micropropagation techniques are being profitably used to overcome the present demand of aromatic and medicinal plants (Rahman et al. 2004). Tissue culture techniques hold promise in this context for rapid multiplication and in vitro production of leaf biomass in $K$. galanga. In vitro production of leaf biomass has also been reported in few other species having commercial implications (Sharada et al. 2007; Kuanar et al. 2009).

The genetic stability of tissue cultured plants is of utmost importance for commercial utilization of the technique for large scale production of true-to-type plants of desired genotype (Mohanty et al. 2008). Out of several molecular markers used for the assessment of the genetic stability, random amplified polymorphic DNA (RAPD) analysis is the simplest, cheapest and quickest method for determining the genetic fidelity of in vitro grown plants as reported in

Table 1. Effect of different growth regulators on shoot and root multiplication in $K$. galanga.

\begin{tabular}{|c|c|c|c|c|c|}
\hline Media Name & $\begin{array}{c}\text { MS Media + Growth regulators } \\
\text { (mg/l) }\end{array}$ & $\begin{array}{c}\text { No. of } \\
\text { shoots/explant } \\
(\text { Mean } \pm \text { SE })^{*}\end{array}$ & $\begin{array}{l}\text { Shoot length (in } \\
\text { cm) } \\
(\text { Mean } \pm \text { SE)* }\end{array}$ & $\begin{array}{l}\text { No. of rootsl } \\
\text { explant } \\
\text { (Mean } \pm \text { SE)* }\end{array}$ & $\begin{array}{l}\text { Root length } \\
\text { (in cm) } \\
(\text { Mean } \pm \text { SE })^{*}\end{array}$ \\
\hline M1 & $\mathrm{BA}(1)$ & $5.0 \pm 0.3^{b}$ & $10.2 \pm 0.3^{d}$ & $5.5 \pm 0.2^{\mathrm{e}}$ & $2.3 \pm 0.1^{d}$ \\
\hline M2 & $\mathrm{BA}(2)$ & $2.8 \pm 0.3^{\mathrm{a}}$ & $4.4 \pm 0.3^{\mathrm{a}}$ & $2.5 \pm 0.2^{b}$ & $1.9 \pm 0.07^{c}$ \\
\hline M3 & $\mathrm{BA}(3)$ & $4.6 \pm 0.4^{b}$ & $5.9 \pm 0.5^{b}$ & $3.8 \pm 0.4^{c}$ & $3.1 \pm 0.07^{f}$ \\
\hline M4 & $\mathrm{BA}(5)$ & $4.5 \pm 0.2^{b}$ & $6.9 \pm 0.8^{b}$ & $4.0 \pm 0.3^{d}$ & $1.2 \pm 0.06^{\mathrm{a}}$ \\
\hline M5 & $\mathrm{BA}(1)+\operatorname{IBA}(0.5)$ & $2.8 \pm 0.3^{a}$ & $3.0 \pm 0.1^{\mathrm{a}}$ & $3.3 \pm 0.3^{c}$ & $2.1 \pm 0.2^{d}$ \\
\hline M6 & $\mathrm{BA}(3)+\operatorname{IBA}(0.5)$ & $4.5 \pm 0.3^{b}$ & $2.9 \pm 0.2^{\mathrm{a}}$ & $2.5 \pm 0.2^{b}$ & $1.9 \pm 0.07^{c}$ \\
\hline M7 & $\mathrm{BA}(1)+\mathrm{IAA}(0.5)$ & $11.5 \pm 0.5^{\dagger}$ & $10.8 \pm 0.6^{d}$ & $4.6 \pm 0.4^{d}$ & $2.3 \pm 0.2^{d}$ \\
\hline M8 & $\mathrm{BA}(3)+\mathrm{IAA}(0.5)$ & $5.8 \pm 0.3^{b}$ & $9.7 \pm 0.4^{d}$ & $3.0 \pm 0.3^{c}$ & $2.2 \pm 0.1^{d}$ \\
\hline M9 & $\mathrm{BA}(3)+\mathrm{IAA}(1)$ & $4.3 \pm 0.3^{b}$ & $6.9 \pm 0.8^{b}$ & $3.6 \pm 0.3^{c}$ & $1.3 \pm 0.04^{b}$ \\
\hline M10 & $\mathrm{BA}(3)+\mathrm{IAA}(0.5)+\mathrm{Ads}(100)$ & $4.5 \pm 0.2^{b}$ & $4.5 \pm 0.4^{\mathrm{a}}$ & $1.6 \pm 0.3^{\mathrm{a}}$ & $1.2 \pm 0.1^{\mathrm{a}}$ \\
\hline M11 & $\mathrm{BA}(3)+\mathrm{IAA}(0.5)+\mathrm{Ads}(50)$ & $4.3 \pm 1.1^{\mathrm{b}}$ & $4.5 \pm 0.6^{\mathrm{a}}$ & $2.3 \pm 0.2^{b}$ & $0.8 \pm 0.2^{\mathrm{a}}$ \\
\hline M12 & $\mathrm{BA}(3)+\mathrm{IAA}(1)+\mathrm{Ads}(100)$ & $6.1 \pm 1.4^{c}$ & $4.1 \pm 0.4^{\mathrm{a}}$ & $2.0 \pm 0.6^{a}$ & $1.0 \pm 0.04^{\mathrm{a}}$ \\
\hline M13 & $\mathrm{BA}(3)+\mathrm{IAA}(1)+\mathrm{Ads}(50)$ & $4.5 \pm 0.2^{b}$ & $7.8 \pm 0.4^{c}$ & $2.8 \pm 0.3^{b}$ & $2.1 \pm 0.06^{d}$ \\
\hline M14 & $\mathrm{BA}(3)+\mathrm{NAA}(0.5)$ & $2.5 \pm 0.5^{a}$ & $2.8 \pm 0.3^{\mathrm{a}}$ & $1.1 \pm 0.1^{\mathrm{a}}$ & $1.6 \pm 0.06^{\mathrm{b}}$ \\
\hline F Value & & 12.58 & 28.07 & 11.45 & 20.41 \\
\hline
\end{tabular}

* a-f: Mean having the same letter in a column were not significantly different at $p<0.005$ level. 


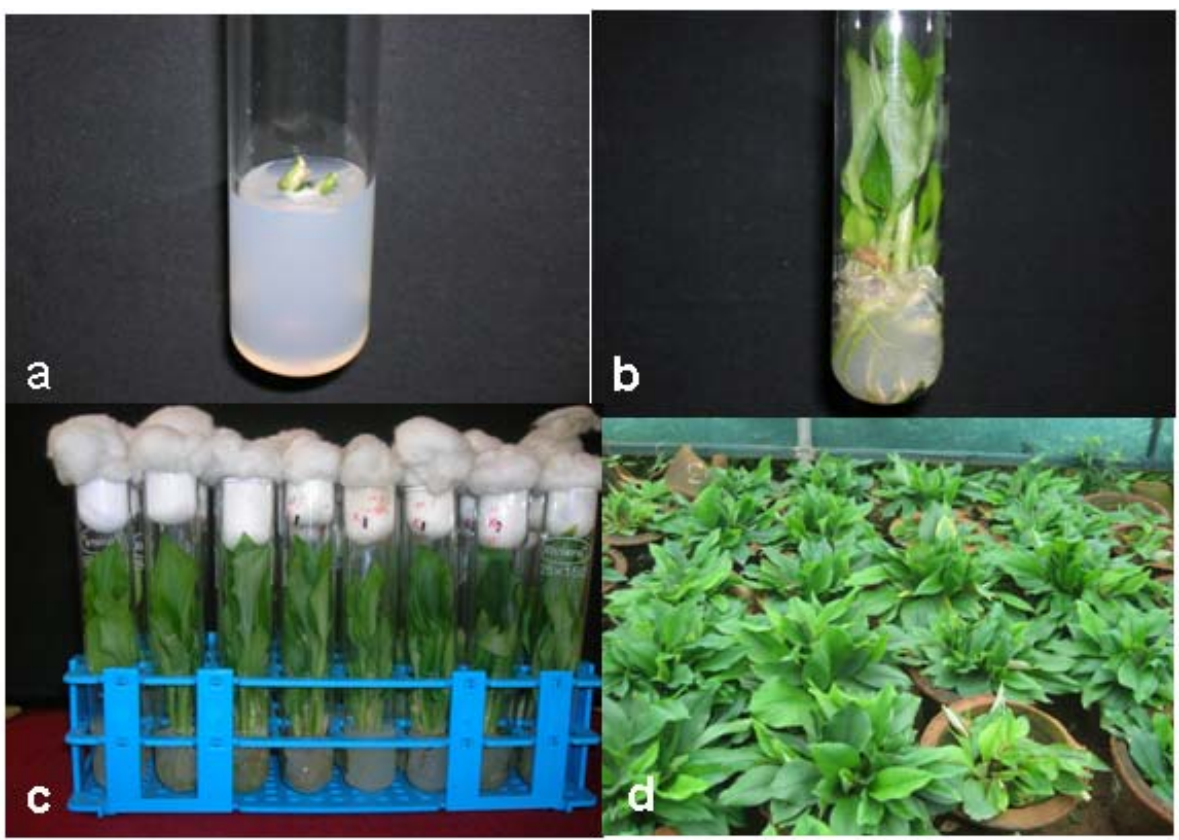

Figure 1.

(a) Explant showing shoot initiation from rhizome bud explant in K. galanga.

(b) Regenerated plants of $K$. galanga with shoots and roots.

(c) Multiplication of plantlets in vitro condition.

(d) Micropropagated plants of $K$. galanga growing under field conditions.

many species (Rout et al. 2002; Martins et al. 2004; Venkatachalam et al. 2007). The few reports so far available on tissue culture studies in K. galanga (Vincent et al. 1992; Shirin et al. 2000; Rahman et al. 2005) do not include any work on in vitro production of extractable leaf biomass for commercial purposes and assessment of genetic stability of micropropagated plants. The present paper deals with a suitable protocol for rapid propagation of genetically uniform plants and a novel method of in vitro production of leaf biomass in K. galanga for the first time.

\section{MATERIALS AND METHODS}

\section{Plant material}

The rhizomes of $K$. galanga were collected from the High Altitude Research Station, Pottangi of Orissa and were grown in the medicinal plant garden of Center Of Biotechnology, Siksha 'O' Anusandhan University, Bhubaneswar. The rhizome sprouted during monsoon (June). The young sprouting buds from rhizome of 10 plants of $K$. galanga were used as explants for culture initiation. The explants were washed under running tap water followed by a neutral liquid detergent (Extran, Merck) for 3 to 5 min. The explants were then washed repeatedly with distilled water and finally surface sterilized with $0.1 \%$ mercuric chloride for 8 to $10 \mathrm{~min}$ in a laminar flow cabinet. Surface sterilized explants were washed 3 to 4 times with autoclaved water aseptically to remove any trace of mercuric chloride prior to cultivation.

\section{In vitro plant multiplication and cultural conditions}

Explants were inoculated to the basal medium of MS (Murashige and Skoog, 1962) with 1-5 mg/l of BA individually or with varying combination of $0.5 \mathrm{mg} / \mathrm{l}$ of IBA, $0.5-1.0 \mathrm{mg} / \mathrm{l}$ of IAA, $0.5 \mathrm{mg} / \mathrm{l}$ of NAA and $50-100$ $\mathrm{mg} / \mathrm{l}$ of Ads (Table 1). The sucrose amount in the media was $30 \mathrm{gm} / \mathrm{l}$. There were ten replicas for each treatment and the experiment was repeated thrice. The medium $\mathrm{pH}$ was adjusted to 5.7 before adding agar and media were autoclaved at $121^{\circ} \mathrm{C}$ and $105 \mathrm{~kg} / \mathrm{cm}^{2}$ of pressure for $20 \mathrm{~min}$. After sterilization of media the explants were transferred into the medium. Culture tubes $(50 \mathrm{ml})$ and conical flasks $(250 \mathrm{ml})$ containing explants were kept under white fluorescent light with $50 \mu \mathrm{mol} /\left(\mathrm{m}^{2} \mathrm{~s}^{2}\right)$ light intensity. Twenty and thirty $\mathrm{ml}$ media were dispensed respectively to culture tubes and conical flasks. Percentage of response of explants with different hormonal combinations was observed time to time and sub culturing was done at two month interval.

\section{Estimation of in vitro leaf biomass yield}

The in vitro grown plants were transferred to MS basal medium supplemented with varying combinations and concentrations of BA, IAA, NAA, Ads. After 8 weeks of growth, leaf biomass in solid and liquid culture, length of shoots and roots, number of shoots and roots were measured from 15 different culture tubes for each treatment. The leaf biomass yield in $250 \mathrm{ml}$ flasks was also 
Table 2. Effect of different growth regulators on leaf biomass yield in $K$. galanga.

\begin{tabular}{|c|c|c|c|}
\hline Media name & $\begin{array}{l}\text { Leaf biomass in liquid } \\
\text { media (in gm/explant) } \\
\qquad(\text { Mean } \pm \text { SE })^{*}\end{array}$ & $\begin{array}{l}\text { Leaf biomass in solid } \\
\text { media (in gm/explant) } \\
\qquad(\text { Mean } \pm S E)^{*}\end{array}$ & $\begin{array}{l}\% \text { of shoot inducing } \\
\text { culture (Mean } \pm \text { SE })^{*}\end{array}$ \\
\hline M1 & $0.3 \pm 0.01^{\mathrm{a}}$ & $3.4 \pm 0.1^{b}$ & $74.2 \pm 0.3^{b}$ \\
\hline M2 & $0.2 \pm 0.01^{a}$ & $3.0 \pm 0.08^{b}$ & $70.2 \pm 0.8^{b}$ \\
\hline M3 & $2.2 \pm 0.01^{c}$ & $5.0 \pm 0.06^{c}$ & $75.0 \pm 0.8^{b}$ \\
\hline M4 & $1.9 \pm 0.01^{b}$ & $2.8 \pm 0.1^{b}$ & $68.8 \pm 0.5^{b}$ \\
\hline M5 & $1.7 \pm 0.00^{b}$ & $0.4 \pm 0.04^{\mathrm{a}}$ & $28.6 \pm 0.7^{\mathrm{a}}$ \\
\hline M6 & $1.4 \pm 0.01^{b}$ & $0.2 \pm 0.03^{\mathrm{a}}$ & $38.8 \pm 0.5^{a}$ \\
\hline M7 & $2.6 \pm 0.01^{c}$ & $7.4 \pm 0.3^{d}$ & $90.0 \pm 1.2^{c}$ \\
\hline M8 & $1.8 \pm 0.07^{b}$ & $4.3 \pm 0.1^{b}$ & $78.2 \pm 1.6^{c}$ \\
\hline M9 & $3.3 \pm 0.01^{d}$ & $3.5 \pm 0.2^{b}$ & $78.8 \pm 0.5^{c}$ \\
\hline M10 & $2.4 \pm 0.01^{c}$ & $0.8 \pm 0.1^{\mathrm{a}}$ & $38.4 \pm 0.8^{\mathrm{a}}$ \\
\hline M11 & $2.3 \pm 0.01^{c}$ & $0.7 \pm 0.1^{a}$ & $38.8 \pm 0.5^{\mathrm{a}}$ \\
\hline M12 & $1.5 \pm 0.01^{b}$ & $2.5 \pm 0.1^{a}$ & $48.4 \pm 0.5^{a}$ \\
\hline M13 & $1.2 \pm 0.01^{b}$ & $2.8 \pm 0.1^{b}$ & $39.6 \pm 0.8^{\mathrm{a}}$ \\
\hline M14 & $1.4 \pm 0.1^{b}$ & $0.5 \pm 0.1^{\mathrm{a}}$ & $29.8 \pm 0.8^{\mathrm{a}}$ \\
\hline F value & 1221 & 173 & 611.1 \\
\hline
\end{tabular}

* a-d: Mean having the same letter in a column were not significantly different at $p<0.001$ level.

calculated after two months. After the first in vitro collection of leaves, shoot bases were separately transferred to culture tubes and flasks for production of another batch of leaf biomass. The process was repeated throughout the year.

\section{Establishment of plants in soil}

In vitro grown plants having well developed shoots and roots were washed gently under running tap water to remove agar from roots and planted in earthen pots containing soil, cowdung and sand mixture in 1:1:1 ratio. The plantlets were kept in greenhouse for acclimatization for 30 days and then transferred to normal field condition for growth until maturity. The percentage of survival was noted.

\section{RAPD analysis}

The genomic DNA of K.galanga was isolated by following the protocol of Doyle and Doyle (1987) with some modification from both in vitro and ex vitro grown mother plants. The crude DNA was purified by adding RNAse A (60 $\mu \mathrm{g}$ for $1 \mathrm{ml}$ of crude DNA solution) followed by washing with phenol:chloroform:isoamyl alcohol (24:24:1) and subsequently with chloroform:isoamyl alcohol (24:1). Then centrifugation was done and the upper aqueous layer was separated and mixed with $1 / 10^{\text {th }}$ volume of $3 \mathrm{M}$-sodium acetate. DNA was precipitated by adding 2.5 volume of chilled absolute ethanol; pellet was dried in vacuum and dissolved in Tris ${ }_{10}$ EDTA $_{1}$ buffer. Quantification of purified DNA was done by analyzing the purified DNA in $0.8 \%$ of agarose gel with a known uncut lambda DNA as standard. Purified DNA samples were then diluted in TE buffer to 25 $\mathrm{ng} / \mu \mathrm{l}$ for RAPD-PCR amplification.

For RAPD analysis a total of 18 random primers were used out of which 15 random decamer primers (Operon Tech, Almeda, USA) from A, C, D and N series (OPA 04, 07, 09, 18; OPC02, 05, 11; OPD03, 07, 08, 12, 18, 20 and OPN04, 16) were selected on the basis of clarity of banding 


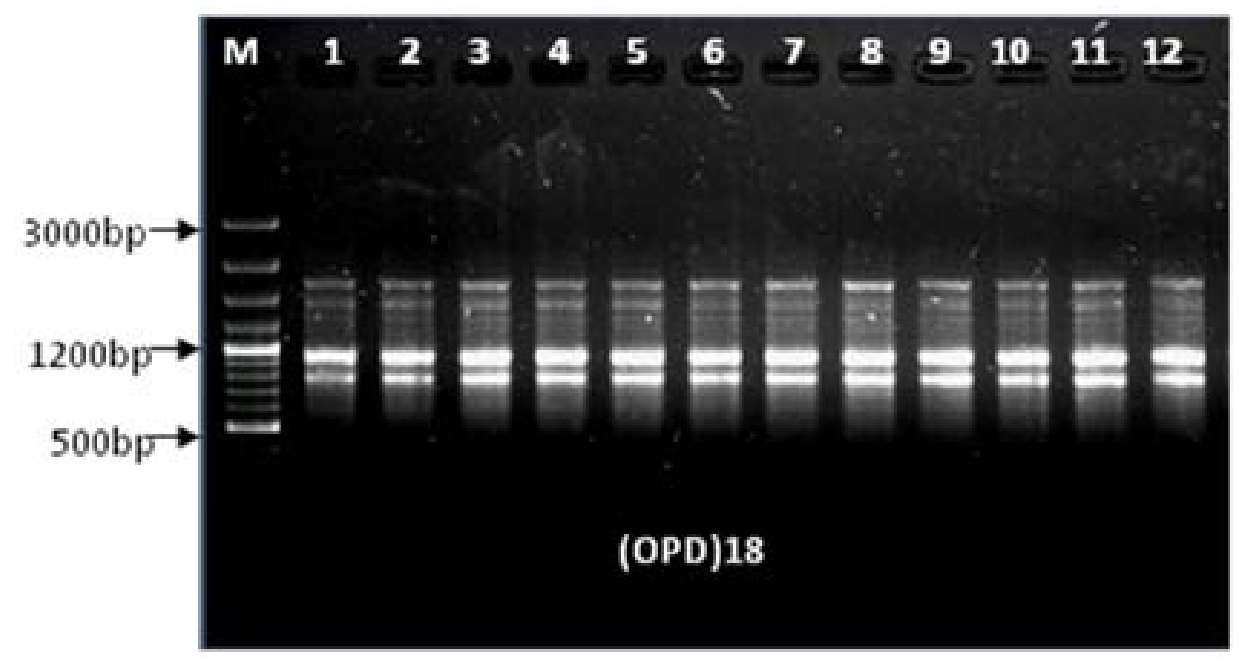

Figure 2. RAPD banding pattern with OPD18 primer in both micropropagated and field grown mother plants (lane 1, mother plant; lanes 2- 12, micropropagated plants).

patterns. The RAPD analysis was performed as per the method of Williams et al. (1990). PCR was performed in a volume of $25 \mu \mathrm{l}$ containing $25 \mathrm{ng}$ of genomic DNA as template, $2.5 \mathrm{ml}$ of $10 \mathrm{x}$ assay buffer $(100 \mathrm{mM}$ Tris hydrogen chloride, $\mathrm{pH}$ 8.3, $500 \mathrm{mM}$ potassium chloride and $0.1 \%$ gelatin), $1.5 \mathrm{mM}$ magnesium chloride, $200 \mu \mathrm{M}$ dNTPs (Bangalore Genei, India), 0.5 unit (U) of Taq polymerase (Bangalore Genei, India) and 15 ng of RAPD primer (Bangalore Genei, India). The amplification was carried out in a thermal cycler (Gene Amp PCR system 9700, Applied Biosystems, CA, USA). In PCR, the first step was performed at initial temperature of $94^{\circ} \mathrm{C}$ for $5 \mathrm{~min}$ for complete denaturation of the template DNA. The second step consisted of 42 cycles having three ranges of temperature, i.e. at $92^{\circ} \mathrm{C}$ for $1 \mathrm{~min}$ for denaturation of template DNA, at $37^{\circ} \mathrm{C}$ for 1 min for primer annealing at $72^{\circ} \mathrm{C}$ for 2 min for primer extension followed by running the samples at $72^{\circ} \mathrm{C}$ for $7 \mathrm{~min}$ for complete polymerization. The PCR products obtained from RAPD were analyzed in $1.5 \%$ agarose gel stained with ethidium bromide $(0.5 \mu \mathrm{g} / \mu \mathrm{l})$ of gel solution in TAE buffer ( $40 \mathrm{mM}$ Tris base, $20 \mathrm{mM}$ sodium acetate, glacial acetic acid to $\mathrm{pH}$ 7.2) for 3 hrs at 60 volts. The size of the amplicons were estimated using 100 bp DNA ladder plus or DNA ladder mix (MBI Fermentas, Lithuania) as standard. DNA fingerprints were visualized under UV light and photographed using Gel Documenting system (Bio-Rad, USA). RAPD analysis using each primer was repeated at least twice to establish reproducibility of banding pattern of different DNA samples of K. galanga.

\section{Statistical analysis}

Data were subjected to analysis of variance for a factorial experiment. Critical differences (CD) were calculated to determine the statistical significance of different treatment means.

\section{RESULTS AND DISCUSSION}

\section{In vitro shoot multiplication and leaf biomass yield}

The rhizome buds of conventionally grown plants were used as explant (Figure 1a) and inoculated to MS media containing varying combinations of BA (1-5 mg/l), IBA (0.5 mg/l), IAA (0.5-1.0 mg/l), NAA (0.5 mg/l) and Ads (50-100 mg/l). Proliferation of shoots was observed in different cultural conditions as mentioned in Table 1. The multiplication of shoot buds occurred in almost all media mentioned above but the rate of multiplication was found to be relatively higher in the media containing BA and IAA combinations. Among the various concentrations maximum multiplication of shoots were found in MS supplemented with BA $(1 \mathrm{mg} / \mathrm{l})$ in combination with IAA $(0.5 \mathrm{mg} / \mathrm{l})$ (Table 1). On this medium, the optimum number of shoots formed was $11.5 \pm 0.6$ shoot/explant and shoot length was $10.8 \pm 0.6 \mathrm{~cm}$. Shoots rooted (Figure $1 \mathrm{~b}$ ) on the same media and the number of roots formed was $4.6 \pm 0.4$ shoot/explant and the root length was $2.3 \pm 0.2 \mathrm{~cm}$. According to Chithra et al. (2005), BA (2 mg/l) and IBA (0.5 mg/l) induced a mean of 8.3 shoots as well as roots within 60 days. In our study, MS media containing NAA and IBA when tried for in vitro shoot multiplication showed no better results. Earlier studies of Shirin et al. (2000), showed that BA (2.7 $\mathrm{mg} / \mathrm{l})$ and NAA $(0.5 \mathrm{mg} / \mathrm{l})$ was effective for the multiplication of $K$. galanga.

An effort was made for in vitro production of leaf biomass of $K$. galanga as an alternative method to conventional harvesting. Collected leaf biomass yield of average (0.2-7.4 gm/explant) in solid media and (0.2-3.3 gm/explant) in liquid media could be obtained at every 8 weeks of culture (Table 2). Leaf biomass yield was optimum in media containing $1 \mathrm{mg} / \mathrm{l} \mathrm{BA}$ and $0.5 \mathrm{mg} / \mathrm{l} \mathrm{IAA}$. The multiplication 
Table 3. RAPD banding pattern of both micropropagated and field grown mother plants in $K$. galanga.

\begin{tabular}{|c|c|c|c|}
\hline Primers & Sequence & Range of amplicons & Total bands \\
\hline OPA04 & AATCGGGCTG & $1400-600$ & 8 \\
\hline OPA07 & GAAACGGGTG & $1975-300$ & 9 \\
\hline OPA09 & GGGTAACGCC & 1300 & 1 \\
\hline OPA18 & AGGTGACCGT & $1600-450$ & 4 \\
\hline OPC02 & GTGAGGCGTC & $1500-550$ & 6 \\
\hline OPC05 & GATGACCGCC & $2500-900$ & 6 \\
\hline OPC11 & AAAGCTGCGG & $1500-1031$ & 5 \\
\hline OPD03 & GTCGCCGTCA & 1031 & 1 \\
\hline OPD07 & TTGGCACGGG & $2200-900$ & 9 \\
\hline OPD08 & GTGTGCCCCA & $2800-1200$ & 4 \\
\hline OPD12 & CACCGTATCC & 850 & 1 \\
\hline OPD18 & GAGAGCCAAC & $1600-700$ & 6 \\
\hline OPD20 & ACCCGGTCAC & $1900-800$ & 5 \\
\hline OPNO4 & GACCGACCCA & $1300-750$ & 5 \\
\hline OPN16 & AAGCGACCTG & $550-250$ & 2 \\
\hline Total & & & 72 \\
\hline
\end{tabular}

(Figure 1c) rate and leaf biomass yield observed in our experiment remained the same in subsequent cultures. The cultures were maintained in the same media with regular sub culturing at 2 months interval. Multiplication rate remained unchanged even after 2 years of culture. Leaf biomass yield was highest in media $\left(\mathrm{M}_{7}\right)$ containing $1 \mathrm{mg} / \mathrm{l}$ BA and $0.5 \mathrm{mg} / \mathrm{l}$ IAA. Leaf biomass yield could also be enhanced from average 7.4 to 14.5 gram/explant by using flasks (250 ml) containing $50 \mathrm{ml}$ MS media instead of culture tubes. During the planting season same plantlets were transferred to the pots and had luxuriant growth. The method revealing 5 times leaf harvesting in $K$. galanga at every 2 months interval has got advantage over conventional method of harvesting which is possible once in a year. Similar method of in vitro leaf biomass production has recently been reported in turmeric (Kuanar et al. 2009) having implication for commercial production of essential oil. Sharada et al. (2007) reported accumulation of withanolites in tissue cultured leaves of Withania somnifera.
Field transfer of regenerants and assessment of genetic stability

The full grown plants with roots and shoots were transferred to pots containing soil, cowdung and sand mixture in 1:1:1 ratio (Figure 1d). Plants were kept for seven days in the culture room and then transferred to green house for acclimatization. After one month, plants were transferred to normal field condition. These plants were subjected to RAPD analysis for assessing genetic stability. About 95\% of plants survived and grew to maturity in field condition.

In order to confirm genetic stability, in vitro and ex vitro grown micropropagated plants were assessed through RAPD analysis. A total of 50 plantlets were analyzed taking minimum 25 plants from each culture group and a minimum of 10 plants were used for each analysis of different culture period. 15 selected RAPD primers gave rise to a total of 72 scorable bands ranging from 250 to 2,800 (Table 3). The number of bands for each primer 
varies from 1-9 with an average of 4.8 bands per primer. A total of 3,600 bands (total number of bands $x$ number of explants analyzed) were generated and all the bands present were monomorphic (Figure 2). Highest number of bands obtained was 9 in case of primers OPA07, OPD07 and lowest number of bands i.e. 1 was obtained in case of primers OPA09, OPD03 and OPD12.

The present study provides the first report on the genetic stability of micropropagated $K$. galanga in vitro obtained from rhizome bud explants using RAPD analysis. RAPD of in vitro grown micropropagated plants has been reported in many other plant species (Rani et al. 1995; Rout and Das, 2002; Martins et al. 2004; Venkatachalam et al. 2007). Panda et al. (2007) reported the genetic stability of micropropagated plants of Curcuma longa by cytophotometric and RAPD analysis. The genetic stability of micropropagated ginger through RAPD analysis was also reported by Mohanty et al. (2008). PCR based molecular markers i.e. RAPD were used to show the genetic integrity because of their cost effectiveness and simplicity. In absence of any variation in the banding pattern in RAPD in all the regenerants analyzed in comparison with the source plants (control), we concluded that the protocol developed could be effectively used as a method for rapid micropropagation and in vitro leaf biomass production of $K$. galanga for commercial utilization.

\section{REFERENCES}

CHAN, E.W.C.; LIM, Y.Y.; WONG, S.K.; LIM, K.K.; TAN, S.P.; LIANTO, F.S. and YONG, M.Y. Effects of drying methods on the antioxidant properties of leaves and tea of ginger species. Food Chemistry, March 2009, vol. 113 , no. 1 , p. $166-172$.

CHITHRA, M.; MARTIN, K.P.; SUNANDAKUMARI, C. and MADHUSOODANAN, P.V. Protocol for rapid propagation and to overcome delayed rhizome formation in field established in vitro derived plantlets of Kaempferia galangal L. Scientia Horticulture, March 2005, vol. 104, no. 1, p. 113-120.

DOYLE, J.J. and DOYLE, J.L. A rapid DNA isolation procedure for small quantities of fresh leaf tissue. Phytochemical Bulletin, 1987, vol. 19, p. 11-15.

KUANAR, A.; MOHANTY, S.; PANDA, M.K. and NAYAK, S. Essential oils from leaves of micropropagated turmeric. Current Science, May 2009, vol. 96, no. 9, p. 1166-1177.

MARTINS, M.; SARMENTO, D. and OLIVEIRA, M.M. Genetic stability of micropropagated almond plantlets as assessed by RAPD and ISSR markers. Plant Cell Reports, December 2004, vol. 23, no. 7, p. 492-496.

MOHANTY, Sujata; PANDA, Manoj K.; SUBUDHI, Enketeswara; ACHARYA, Laxmikanta and NAYAK,
Sanghamitra. Genetic stability of micropropagated ginger derived from axillary bud through cytophotometric and RAPD analysis. Zeitschrift fur Naturforschung C, 2008, vol. 63, p. 747-754.

MURASHIGE, Toshio and SKOOG, Folke. A revised medium for rapid growth and bioassays with tobacco tissue culture. Physiologia Plantarum, July 1962, vol. 15, no. 3, p. 473-479.

PANDA, Manoj Kumar; MOHANTY, Sujata; SUBUDHI, Enketeswar; ACHARYA, Laxmikanta and NAYAK, Sanghamitra. Assessment of genetic stability of micropropagated plants of Curcuma longa L. by cytophotometry and RAPD analysis. International Journal of Integrative Biology, 2007, vol. 1, no. 3, p. 189-195.

RAHMAN, M.M.; AMIN, M.N.; AHAMED, T.; ALI, M.R. and HABIB, A. Efficient plant regeneration through somatic embryogenesis from leaf base derived callus of Kaempferia galanga L. Asian Journal of Plant Sciences, 2004, vol.3, no. 6, p. 675-678.

RAHMAN, M.M.; AMIN, M.N.; AHAMED, T.; AHMAD, S.; HABIB, I.A.; AHMED, R. and AHMED, M.B. In vitro rapid propagation of black thorn (Kaempferia galanga $\mathrm{L}$.): A rare medicinal and aromatic plant of Bangladesh. Journal of Biological Sciences, 2005, vol. 5, no. 3, p. 300-304.

RANI, Vijay; PARIDA, Ajay and RAINA, S.N. Random amplified polymorphic DNA (RAPD) markers for genetic analysis in micropropagated plants of Populus deltoids Marsh. Plant Cell Reports, April 1995, vol. 14, no. 7, p. 459-462.

ROUT, G.R. and DAS, P. In vitro studies of ginger: A review of recent progress. In: GORIL, J.N.; ANAND KUMAR, P. and SINGH, V.K. eds. Recent Progress in Medicinal Plants, vol. 4, Biotechnology and Genetic Engineering, Science Technology Publication, Studium Press, Houston, TX, USA, 2002, p. 307-326.

SHARADA, M.; AHUJA, A.; SURI, K.A.; VIJ, S.P.; KHAJURIA, R.K.; VERMA, V. and KUMAR, A. Withanolide production by in vitro cultures of Withania somnifera and its association with differentiation. Biologia Plantarum, March 2007, vol. 51, no. 1, p. 161-164.

SHIRIN, Fatima; KUMAR, Sandeep and MISHRA, Yogeshwar. In vitro plantlet production system for Kaempferia galanga, a rare Indian medicinal herb. Plant Cell, Tissue and Organ Culture, December 2000, vol. 63, no. 3, p. 193-197.

SULAIMAN, M.R.; ZAKARIA, Z.A.; DUAD, I.A. and HIDAYAT, M.T. Antinociceptive and anti-inflammatory activities of the aqueous extract of Kaempferia galanga leaves in animal models. Journal of Natural Medicines, 2008, vol. 62, no. 2, p. 221-227. 
Parida, R. et al.

VENKATACHALAM, L.; SREEDHAR, R.V. and BHAGYALAKSHMI, N. Genetic analysis of micropropagated and regenerated plantlets of banana as assessed by RAPD and ISSR markers. In Vitro Cellular \& Developmental Biology - Plant, June 2007, vol. 43, no. 3, p. 267-274.

VINCENT, K.A.; MATHEW, K. and HARIHARAN, M. Micropropagation of Kaempferia Galanga L. - a medicinal plant. Plant Cell, Tissue and Organ Culture, February 1992, vol. 28, no. 2, p. 229-230.

WILLIAMS, John G.K.; KUBELIK, Anne R.; LIVAK, Kenneth J.; RAFALSKI, J. Antoni and TINGEY, Scott V. DNA polymorphisms amplified by arbitrary primers are useful as genetic markers. Nucleic Acids Research, October 1990, vol. 18, no. 22, p. 6531-6535. 